\title{
Editorial
}

\section{O design da informação no espaço público}

Este número da InfoDesign reúne artigos selecionados a partir da chamada de trabalhos para o CIDI 2015 e CONGIC 2015. Como sempre, selecionamos artigos entre aqueles com as melhores avaliações, e entre eles buscamos formar um grupo com temática convergente. O tema destacado nesta edição é o design da informação no espaço público, e os artigos selecionados examinam esta questão no contexto das cidades de Brasilia, Londres, Pelotas, Porto Alegre, Recife, São Paulo e Vitoria.

Os dois primeiros artigos estão relacionados a experiências de ensino na graduação. O artigo de Fátima Aparecida dos Santos, professora da UnB e uma das organizadoras do CIDI 2015, trata de experiência didática com seus alunos de graduação, durante a qual desenvolveram projetos para transformar "espaços de desesperanças" identificados em Brasilia em "espaços de esperança” através do design da informação. Em seguida, Fabiano de Vargas Scherer, Gabriel Bischoff Scherer, da UFRGS, discutem os métodos empregados em um trabalho de conclusão de curso que teve como foco a identidade visual, o design da informação e o design de orientação (ou wayfinding) associados à Linha Turismo, serviço de city tour com ônibus de dois andares oferecido pela Secretaria Municipal de Turismo de Porto Alegre. Enquanto Santos convoca o "olhar do arquiteto rebelde" sugerido por David Harvey e o conceito de affordance trabalhado por Donald Norman para chegar a propostas transformadoras para espaços esquecidos, Scherer e Scherer examinam métodos de design de comunicação, design gráfico ambiental e design de marca para chegar à proposta de uma metodologia adequada diagnosticar e aprimorar um serviço que tem como objetivo dar a conhecer os espaços da cidade.

$\mathrm{O}$ terceiro artigo fala sobre um método de mapeamento empregado no desenvolvimento do sistema de sinalizacão do campus Goiabeiras da UFES, projeto desenvolvido pelo ProDesign Ufes - Laboratório de Projetos em Design, núcleo de pesquisa e extensão ligado ao Departamento de Desenho Industrial da universidade. A ênfase aqui foi na visualização de informações obtidas durante coleta de dados baseada em método de design centrado no usuário. Os autores, Mauro Pinheiro, Ricardo Esteves Gomes e Matheus Rocha de Souza Ramos, os dois primeiros professores e o terceiro aluno do bacharelado em Design da instituição, descrevem, como principal resultado, uma técnica para visualização de fluxos e intensidade de trajetos. Tal técnica deve auxiliar na tomada de decisões sobre as próximas etapas do projeto, que envolve sinalizar outros campi da UFES.

Os dois últimos artigos tem como foco a pesquisa sobre tipografia e letreiramento no ambiente urbano, ou 'paisagens tipográficas', tema tratado em artigos publicados nos volumes 4 (2007) e 6 (2009) da 
InfoDesign, dos quais sou co-autora. Em seu estudo sobre elementos tipográficos inseridos em fachadas e tampas de bueiro, Daniela Brisolara, professora do Instituto Federal Sul Rio-grandense, demostra que os métodos de pesquisa descritos nos volumes 4 e 6 da InfoDesign, utilizados no contexto de São Paulo e Rio de Janeiro, puderam ser adotados com sucesso para a coleta de dados sobre tipografia arquitetônica e tipografia de registro em Zonas de Preservação do Patrimônio Cultural de Pelotas. Em meu artigo, apresento alguns resultados de estudo comparado sobre epígrafes arquitetônicas e londrinas, destacando aspectos relevantes para o design da informação, tais como a localização, tamanho, configuração tipográfica e conteúdo destas inscrições. Ambos os artigos demontram a importância do estudo das letras, números e sinais aplicados em fachadas de edifícios para a preservação do patrimônio material e cultural das cidades, e sua relevância para o sentido de identidade e de lugar.

Finalmente, na seção de Iniciação Científica, o artigo de Madyana Torres e Hans Waechter, da UFPE, abordam a relação entre a cidade e seus habitantes, tendo como foco o bairro de Casa Amarela no Recife. Durante seu TCC, através de estratégias de design participativo, Torres, que hoje é aluna do mestrado em design de interação da Universidade de Umeå, na Suécia, desenvolveu o projeto de um aplicativo e website que controlam a projeção de mensagens da comunidade em uma tela instalada no mercado central do bairro.

Tenho certeza de que estes artigos, destacados pelos criteriosos pareceristas dos eixos temáticos de comunicação, sociedade e teoria \& história do CIDI e do CONGIC, fornecerão inspiração e servirão como referência para outras pesquisas acerca do design da informação no espaço das cidades.

\section{Priscila L. Farias}

Editora 